\title{
LUT
}

University

\section{Sustainable system value creation: Development of preliminary frameworks for a business model change within a systemic transition process}

Koistinen Katariina, Laukkanen Minttu, Mikkilä Mirja, Huiskonen Janne, Linnanen Lassi

This is a Author's accepted manuscript (AAM) version of a publication published by Springer, Cham

in Sustainable Business Models. CSR, Sustainability, Ethics \& Governance.

DOI: $10.1007 / 978-3-319-73503-0 \_6$

Copyright of the original publication: (C) Springer International Publishing AG 2018

Please cite the publication as follows:

Koistinen K., Laukkanen M., Mikkilä M., Huiskonen J., Linnanen L. (2018) Sustainable System Value Creation: Development of Preliminary Frameworks for a Business Model Change Within a Systemic Transition Process. In: Moratis L., Melissen F., Idowu S. (eds) Sustainable Business Models. CSR, Sustainability, Ethics \& Governance. Springer, Cham

This is a parallel published version of an original publication. This version can differ from the original published article. 


\section{TITLE}

Sustainable system value creation: Development of preliminary frameworks for a business model change within a systemic transition process

\section{AUTHORS}

Katariina Koistinen ${ }^{1}$, Minttu Laukkanen ${ }^{1}$, Mirja Mikkilä ${ }^{1}$, Janne Huiskonen ${ }^{1}$ and Lassi Linnanen ${ }^{1}$

${ }^{1}$ Lappeenranta University of Technology, POBox20, FI-53851 Lappeenranta, Finland

\section{ABSTRACT}

Although corporate sustainability has gained more attention and companies have recently showed a growing interest in sustainable practices, the progress towards sustainable development has been slow leading to increasing environmental and social challenges. . Business model innovations are recognized as a key to the creation of sustainable business and as a bridge between company level and system level changes. Sustainable business model innovations create, deliver and capture economic, social, and ecological value for customers and other stakeholders in various societies.

The aim of this article is to deepen the understanding of the ways how companies create and capture sustainable value through business models in a larger operation system. From the theoretical perspective, the article adopts the transition theory and the concept of strong sustainability for understanding socio-technical transitions and business model changes towards sustainability. Here the focus is on companies' dualistic role pursuing sustainable development targets - both contributing to sustainability within the business dimensions, and assisting the broader systemic change through the new sustainable business models. Furthermore, the article deals with the external factors that either enable or hinder companies to transform their existing business models towards sustainability.

By reviewing previous literature, this study develops preliminary frameworks combining the approaches of transition management, sustainable value creation and corporate sustainability levels. The work aims to decrease the existing gap between the literature of system transition and business models. The frameworks can be applied in the future in analyzing new sustainable business models, value processes, value creation and capture, and broader systemic changes towards sustainability. 


\section{INTRODUCTION}

The number of publications on corporate sustainability has increased exponentially since the early 1990s (Linnenluecke \& Griffiths, 2013), and companies overall are showing increasing interest towards corporate sustainability practices (e.g. Lacy et al., 2012). However, the progress towards sustainable development has been slow, and ecological and social problems are increasing. Dyllick and Muff (2015) identified a significant disconnection between the organizational, micro-level concepts of corporate sustainability and sustainable business and the global, macro-level concept of sustainable development. Company-level actions contribute marginally to global sustainability if corporate sustainability and sustainable development are disconnected, and consequently, the performance measures remain disconnected. Three conceptual challenges disconnecting the concepts of corporate sustainability and sustainable development were addressed: 1) the poor integration of all three dimensions (economic, ecological and social) in the business sustainability discourse, 2) the insufficient integration of the societal macro level with the organizational micro level, and 3 ) the focus on economic success as the dominating performance measure.

The concept of the business model is presented as a bridge between changes at the company leve, micro level, and the system level, macro level (Boons \& Lüdeke-Freund, 2013; Boons et al., 2013). Monumental challenges, such as climate change, resource depletion and inequality, question the traditional manner in which companies create value. Innovations promoting the sustainable performance of companies are more crucial than ever for longterm success, and sustainability issues should be fully integrated into the strategy and operations of a company (Lacy et al., 2012). Sustainable business model is an approach for firms to reconceptualize their purpose and value creation logic to improve their economic, environmental and social sustainability (Bocken et al., 2014)., and sustainability can be seen as a central driver of innovation (Nidumolu et al., 2009). Although the question of how companies can transform their business models towards sustainability is highly relevant for society and management, and sustainable business model literature is evolving, companies have been slow to adopt sustainability strategies and sustainable business models. Sustainability transitions are complex and unique because sustainability is a collective good, which means that most sustainable solutions do not offer direct user benefits (Geels, 2011). It is therefore unlikely that sustainable business model will be able to replace existing systems without wider system level changes, such as changes in regulatory frameworks and industry level policies.

Firms are capable of contributing to sustainability through multiple transition pathways (Geels \& Schot, 2007; Geels, 2014) when firms can be interpreted as agents of sustainability transitions. Transition literature typically perceives business enterprises as external agents that challenge the status quo, whereas the internal processes of firms are often underplayed. The processes of value creation and capture within business environments are needed to understand both business model change and system transition.

In addition, business models are typically considered from the viewpoint of a focal company, and to date, business model research has predominantly focused on company level analyses and examples, whereas sustainability often requires a broader, system level perspective (Abdelkafi \& Täuscher, 2016; Gorissen et al., 2016; Pedersen et al., 2016). Internal activities 
through which companies enhance sustainable business are greatly affected by the business environment in which the companies operate (Zott \& Amit, 2007). It is thus important to take a step beyond the business model of the individual company and identify and analyze driving forces and barriers that have an impact on sustainable business models. A deeper understanding is required on the mechanisms on how the business model concept can bridge corporate sustainability and system level innovation. System level change and industry transformation require the joint efforts of several actors and the change of more than one company's business model.

This study contributes to these calls by applying transition theory to explain both the business model change at the company level and wider socio-technical transition towards sustainability. Transitions emerge through agency that can be, for example, an individual, a business enterprise, or a governmental or non-governmental organization. The article aims at explaining the mechanisms of sustainable value capture and creation at the company level but within a larger operating system.

This paper is organized into two main sections and conclusions. The next section reviews the literature from different disciplines and presents the central concepts of the study and the theoretical background related to them. The following section integrates the disciplines and ends up presenting preliminary frameworks emerging from the relevant theories. The initial integration of different disciplines may help to reduce the gap between system transition literature and business model literature. The final section draws conclusions and presents implications and avenues for future research. Since the focus of this chapter is theoretical, the proposed future research directions include testing the frameworks empirically.

\section{THEORETICAL AND METHODOLOGICAL BACKGROUND}

Previous literature was reviewed in order to create the basis on understanding socio-technical transitions and business model change towards sustainability. The qualitative literature analysis (see e.g. Marshall and Rossmand, 1999, Miles and Huberman, 1994) was conducted in two iterative stages. First, we identified the main concepts and conducted the literature review. Second, we used constructive research to synthesize the findings from the previous literature and to develop the integrative frameworks. We used the Scopus database and the following keywords and their combinations to find relevant articles: 'business model', 'sustainability', 'transition management', 'system transition' and 'systemic change'. (Scopus is an extensive database and probably the best tool available for literature searches, particularly for articles published after 1995 (Falagas et al., 2008). Falagas, M.E., Pitsouni, E.I., Malietzis, G.A. \& Pappas, G., 2008, "Comparison of PubMed, Scopus, Web of Science, and Google Scholar: Strengths and weaknesses", FASEB Journal, vol. 22, no. 2, pp. 338-342.)

Based on three key concepts identified - namely, sustainability, business model and system transition - the conceptual framework was outlined for integrating business model change and system transition towards sustainability (Figure 1). The key concepts are discussed in this section. The synergy between the disciplines is created based on the findings of the discussion in the following section. 


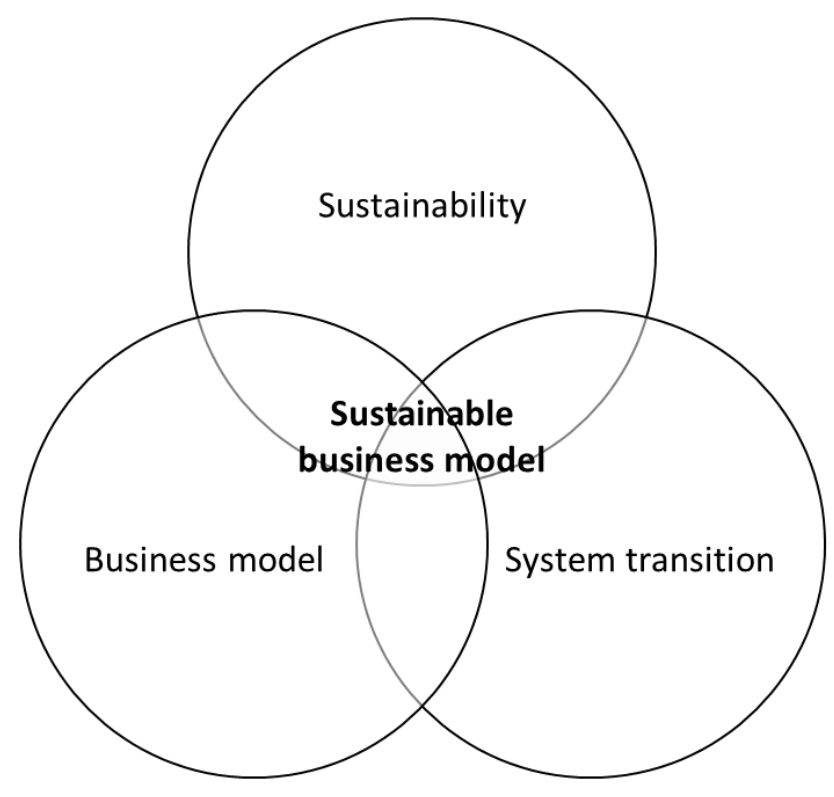

Figure 1. Conceptual framework for sustainable value creation

\section{Concept 1: Sustainability}

\section{Planetary boundaries}

Since the world faces mounting sustainability threats and great challenges, researchers have attempted to determine sustainable limits to human activities. After the Industrial Revolution, human actions have been the main drivers of global environmental change, hence pushing the Earth outside of its stable environmental state with consequences that are detrimental or even catastrophic for large parts of the world. Rockström et al. (2009) have developed "planetary boundaries" that define the safe operating space for humanity with respect to the Earth's system and are identified in terms of the planet's biophysical subsystems or processes. Steffen et al. (2015) addressed the impact of accelerating economic growth and equity for the changing safe operating space. Milne et al. (2006) emphasized management approaches to corporate responsibility in this context. The debate has led to investigating on the contribution of companies to the degradation of the nine specific boundary processes on different focal scales (Whiteman et al. 2013).

\section{Sustainability}

WCED (1987) defined sustainability as the development meeting the present needs without compromising the ability of future generations to meet their own needs. Within this view, pursuing sustainability is seen as a process of gradually conjoining demands on and the supply of resources, the infinite and finite aspects of human life (Williams \& Millington, 2004). Traditionally, sustainable development is portrayed as a convergence, or a triple bottom line, of three different pillars: economic, ecological and social (e.g. Mikkilä, 2006, Mikkilä et al., 2015).

The debate by scholars and practitioners culminated into the categories of weak sustainability and strong sustainability. The distinction between weak and strong sustainability was derived from the attempts to operationalize sustainability in a purposeful way. Weak sustainability 
refers commonly to a need to expand the stock of resources by, for example, developing renewable resources, making more out of existing resources or finding technological solutions to environmental problems (Williams \& Millington, 2004). The idea underlying strong sustainability is to revise the demands on the Earth. For instance, the consumption should be decreased, rather than adapting the Earth to suit human needs (Williams \& Millington 2004). The distinction between weak and strong is, however, rather crude and the reality much more diverse.

\section{Sustainable development related to corporate sustainability}

The idea of sustainable development is often dominated by the macro level. Baumgartner and Ebner (2010) argued that sustainable development is designated only at the macro level of societies. Comprehensive corporate sustainability strategy eventually have positive effects on societies at large. This micro level sustainability refers commonly to corporate sustainability or responsibility including the three dimensions of economic, environmental and social sustainability (Mikkilä, 2006; Mikkilä et al., 2015) Corporate sustainability is a valuebound concept that varies in place and time depending on the surrounding, dominating regime. Corporate sustainability and responsibility refer commonly to the operation environment: natural resource based industries favor corporate sustainability, whereas several other sectors apply corporate responsibility (Mikkilä \& Toppinen, 2008; Mikkilä et al., 2016).

The research on how corporations can contribute to sustainability has continued over the past decade and, for example, Dyllick and Muff (2015) have introduced a four-level typology for corporate sustainability in order to clarify when business is truly sustainable. These levels are "business-as-usual", "refined shareholder value management", "managing for the triple bottom line" and "truly sustainable business". The first focuses on producing economic value in the form of profit and shareholder value, and externalized costs are not understood or measured. At the second level, the business objective is to create shareholder value, but environmental and social concerns are considered in decision-making and actions as economic risks but also opportunities for business. At the third level, value creation goes beyond shareholder value, including social and environmental values. This means a broadened stakeholder perspective, pursuing a triple bottom line approach, and creating sustainable value not just as a side-effect of business activities but as the result of deliberately defined goals. The highest level, truly sustainable business, shifts the perspective from the traditional "inside-out" approach to "outside-in", referring to the creation of a significant positive impact in critical and relevant areas for society and the planet in addition to the mitigation of negative impacts. Sustainability challenges are turned into business opportunities making "business sense" of environmental and social issues.

\section{Concept 2: Business model}

\section{Business model innovation}

A business model describes the rationale on value creation, delivery and capture of organizations (Osterwalder \& Pigneur, 2010). It reflects the company's realized strategy (Casadesus-Masanell \& Ricart, 2010), emphasizes a holistic approach to explaining how companies "do business" (Zott et al., 2011) and provides a link between an individual company and the larger production and consumption system (Boons et al., 2013). The 
business model describes how and to whom to do business in addition to what a business does (Zott \& Amit, 2010).

Business model innovation is widely acknowledged as a source of innovation (Zott \& Amit, 2007; Amit \& Zott, 2012) and as a key source of competitive advantage (Baden-Fuller \& Morgan, 2010; Chesbrough \& Rosenbloom, 2002; Teece, 2010). It is also recognized as key to the creation of sustainable business (e.g. Boons et al., 2013; Boons \& Lüdeke-Freund, 2013; Carayannis et al., 2014) and the enhancement of the transition towards a circular economy (e.g. Lewandowski, 2016; Planing, 2015). Comprehensive sustainability efforts are more likely to take place in organizations that demonstrate high levels of business model innovation (Pedersen et al., 2016).

\section{Business model for sustainability}

Business models for sustainability, i.e. sustainable business models, significantly increase positive impacts or reduce negative ones for societies by changing value creation, delivery and capture by organizations and their networks (Bocken et al., 2014). According to Schaltegger et al. (2012; 2016), sustainable business modeling aims at identifying opportunities that allow firms to capture economic value whilst generating environmental and social value, thereby establishing the business case for sustainability. A business model that contributes to sustainable development needs to create value to the whole range of stakeholders and the natural environment, beyond customers and shareholders (Schaltegger et al., 2016). Upward and Jones (2016) have presented a more theoretical approach; they discuss weak and strong sustainability and compare more profit-oriented business models to strongly sustainable business models building on the natural and social science of sustainability. They see that strongly sustainable business models do no harm but create positive environmental, social, and economic value throughout the value networks, thereby sustaining the possibility that human and other life can flourish on this planet forever. Strongly sustainable business models take financial, societal and environmental costs into account and measure financial rewards, social benefits and environmental regeneration - so called tri-profit.

Stubbs and Cocklin (2008) defined a sustainable business model to draw economic, environmental and social aspects of sustainability in defining a company's purpose and measuring its performance, considers the needs of all stakeholders, treats nature as a stakeholder, and encompasses both a system and a company-level perspective. Abdelkafi and Täuscher (2016) emphasized the system-level perspective by conceptualizing a sustainable business model, that enables the company to reinforce the mutual interdependencies between the value created for its customers and the environment as well as the value captured for itself. The more value the company can create for its customers and the wider environment, the higher the value it captures for itself.

The literature has identified a wide range of examples on specific companies aiming at contributing to business model innovation for sustainability, for example Interface Inc. and Bendigo Bank (Stubbs \& Cocklin, 2008), and British Sugar (Short et al., 2014). Some examples show solutions and mechanisms of extended producer responsibility and end-of-life strategies (Rizzi et al., 2013), product-service systems (Tukker, 2015), base of pyramid solutions (Chaurey et al., 2012), and collaborative consumption (Bardhi \& Eckhardt, 2012).. 


\section{Business model change towards sustainability}

Business model innovation covers changes from incremental adjustments to more radical and systemic changes (Cavalcante et al., 2011). The innovations required for sustainable development need to move beyond incremental adjustments (Johnson \& Suskewicz, 2009; Boons et al., 2013). Gauthier \& Gilomen (2016) proposed a four-stage typology of the business model transformations where the first two stages represent business as usual or incremental innovation and marginal modifications to business model elements without major changes to the whole value delivery system, and the latter two more radical innovation. These four stages are: "business model as usual", "business model adjustment", "business model innovation", and "business model redesign". Business model innovation refers to major business model transformations and the strong potential of new value propositions and value creation mechanisms, and business model redesign refers to a complete rethinking of companies' business model elements to bring radically new value propositions to the market. From the sustainability perspective, the first stage could mean pollution prevention, cleaner production and good working conditions within legal and other external standards, whereas designing products for sustainability, resource efficiency and sustainable marketing and communication with stakeholders are covered at the second stage. The third stage highlights designing whole processes for sustainability. At the highest, the fourth level, companies see sustainability as a real business opportunity and source of differentiation. Companies translate sustainability challenges into business opportunities by making "business sense" of societal and environmental issues (Dyllick \& Muff, 2015). Shifting from traditional energy business to solar energy-based solutions business represents an example of a sustainability based business.

\section{Concept 3: System transition}

\section{System transition and multi-level perspective (MLP)}

Previously, the literature on environmental innovation was dominated by single technologies, such as developing wind turbines or biofuels. The multi-level perspective brings together both technological and social approaches to system transition, hence being one of the leading theories regarding sustainability transitions in the socio-technological system (Geels, 2011). MLP explains trajectories of sustainability transitions. Emerging sustainability innovations challenge and aim at replacing the existing, typically unsustainable system (Geels \& Schot, 2007; Geels, 2011). MLP is based on the assumption of the three-level structure: niche level, regime level and landscape level. Technological trajectories locate in the socio-technical landscape, consisting of a set of deep structural trends, such as economic growth or oil price (Geels, 2002).

The landscape is described as an external structure or context for interactions of actors. Regimes refer to rules that enable and constrain activities within communities, whereas the landscape refers to wider technology-external factors. (Geels, 2002) The landscape is constantly transforming, but relatively slowly compared to regimes. Regimes generate incremental innovations, whereas radical innovations are generated in niches (Geels, 2002).

Genus and Coles (2008) and Berkhout et al. (2005) criticized the definition of transitions being problematic overall, being challenging to specify the start and end of transitions. Markard and 
Truffer (2008) argued that the definition of a regime is incoherent in MLP and regimes can bedefined at different levels of combination and from different perspectives. Moreover, MLP has steadily discussed policies as steering methods within the framework, but the policy is often an external force that is not actually implemented in the socio-technical transition (Smith et al. 2010). One of the critiques against MLP considers agency and how it isunderplayed in the framework. Sometimes MLP falls to focus on the technological transition rather than agency that has the capability to transform the existing regime (Smith et al., 2005; Genus \& Coles, 2008).

\section{Agency and MLP}

Agents are capable of creating and advancing sustainability transitions and sustainable value. Agency is understood here as the capacity of performing acts that contribute to sustainability. The representations of agency can appear as both individuals and larger groups, such as firms pursuing sustainability. Several scholars recognize that agency plays a crucial role in sustainable transitions as a part of MLP. For example, Grin et al. (2011) and King (2008) suggested that agency creates change, having a necessary role during particular episodes of a transition. Agency typically possesses abilities, means, and power for deliberative action on multiple scales to contribute to sustainability (Wiek et al., 2012). Agency also deeply influences the internal translation and interpretation of sustainability and helps to embed it further (Lehner, 2014; Heijden, van der Cramer \& Driessen, 2012).

\section{Agency shaping the system}

The power of agency lies in its potential to shape the prevailing regime. Most pioneering studies suggested that agency could be the most effective element in creating lasting transition for better future (Walker et al., 2010; Fudge, Peters \& Woodman, 2016). MLP framework recognizes the agents to be capable to introduce transitions outside the prevailing regime, and discursive activities at regime and niche levels eventually result in cultural repertoires at the landscape level (Geels \& Schot, 2007; Geels \& Verhees, 2011; Geels, 2011). The ability of achieving a more sustainable system ultimately depends on agency, which drives niche innovations and implements regime changes or connects niches and regimes (Grin, Rotmans \& Schot, 2011).

Agents shape the prevailing system by challenging the current regime. To challenge the prevailing regime, niche innovations have to achieve legitimacy, which is required for an innovation to initially become relevant and in the end dominant in the system (Bork et al. 2015; Haxeltine \& Seyfang, 2009). Legitimacy is achieved by surpassing resistance to change. Resistance from the current regime is likely since agents ultimately challenge the existing system. The current regime also embodies power: the rules, resources and actor configurations which are part of the regime will privilege particular practices over others (Grin, Rotmans \& Schot, 2011). Whereas the incumbent regime uses its power to create resistance towards transition, it is also true that regime changes eventually result in changes in power relations (Grin, Rotmans \& Schot, 2011). The challenge for regime shaping agents lies in making transition dynamics and the political dynamics associated with it to reinforce each other generously to gradually destabilize the harmony of power and legitimacy between incumbent and sustainable practices, which consequently may lead to merging through common visions or through the graduate, self-reinforcing structuring of practices (Grin, Rotmans \& Schot, 2011). 


\section{From multi-level perspective (MLP) to triple embeddedness framework (TEF)}

MLP has dominated the related sustainability transition theories even though it has been rather policy oriented and paid marginal attention to the business environment. To address this gap, Geels (2014) developed a new conceptual framework, the triple embeddedness framework (TEF) acknowledging interactions between incumbent business firms and operation environments. The interactions between business industries and their economic and socio-political environments were conceptualized as bi-directional.

The major global challenges, such as climate change, energy security, transport and resource efficiency, and food safety, are results of negative externalities for incumbent firms in industries, such as, oil or coal (Geels, 2014). These typically unsustainable systems are rigid and filled with various lock-in mechanisms (Geels, 2011). A stable incumbent regime is the outcome of various lock-in processes and it reinforces itself as conflicting to novel innovations (Klitkou et al. 2015). In addition, incumbent firms typically embody power and internal resources and incumbents use their adaptive capacity to orient emerging transition trajectories into a path set in the parameters of the current regime (Geels \& Schot, 2007). For this reason incumbent firms tend to prefer incremental change and the continuation of existing trajectories (Geels, 2014). However, incumbent firms can also adopt innovations that are developed in niches and then utilized in regimes, which gradually trigger further changes in the regime (Geels \& Schot, 2007). In addition, large incumbent firms can also develop and market radical innovations and hence have an influence on confronting grand challenges (Geels, 2014). Incumbents may display many ambivalent strategies (Bakker et al., 2012). Consequently, incumbent firms bear the potential in contributing to sustainability through multiple pathways.

The underlying assumption of TEF is that a mismatch between widespread institutions, such as broadly accepted norms, values, belief systems, and industry-specific institutions, does not generate pressure on firms as such. Pressure is rather created through activities - for example, complaints, demands and criticisms by socio-political actors, such as consumers, policymakers, civil society and social movements (Geels, 2014). Consequently, the purpose of TEF is that increasing pressure towards incumbent industries might result in incumbent firms to overcome lock-in mechanisms and reorient towards more radical innovations (Geels, 2014). This is crucial since in addition to incremental innovations, the mounting challenges of the world need radical innovations. Since large firms are capable of pursuing sustainability, they can be seen as agents of sustainability transitions, and consequently, creating sustainable value. Since sustainability transitions have multiple possible pathways, transitions also include multiple types of agency (Geels \& Schot, 2007). Firms as agencies can be interpreted as two-fold. Firstly, firms are able to contribute to sustainability within the limits of the current regime related with the concept of weaker sustainability and sustainable development through incremental innovation. Secondly, large firms are capable of acting as agents of radical innovations of sustainability if they are able to overcome the lock-in mechanisms of the existing system.

\section{BUILDING AN INTEGRATION BETWEEN DIFFERENT DISCIPLINES}

\section{Integrative concept: Value}




\section{Different forms of value}

Value is a multifaceted and elusive concept, which is used as a central construct in the form of value propositions when analyzing market opportunities (Anderson et al., 2006) and designing business models (Osterwalder \& Pigneur, 2010). From the economic point of view, the two most common notions of value are exchange value and use value. The first one refers to the price of an item in the market, and the latter is determined by how useful an item is to a given person or situation (value-in-use, value-in-context). The latter view has been promoted especially by the service researchers since services are more intangible (e.g. Vargo et al., 2006). In business, it is most relevant to analyze value from the customer's point of view; that is, the value of the supplier's offering for the customer. In this view, value is normally understood as some form of assessment of perceived benefits against sacrifices required by the customer (e.g. Woodall, 2003). Customer value is, however, a narrow definition of value if we look at larger systems of stakeholders and different perspectives into value. From the system's point of view, besides customer value, we should also consider value for the organization, ecosystem and society, and understand value as not only economic, but as a psychological, sociological and ecological concept (den Ouden, 2012). Only then can we approach what sustainable value as a whole in a system under study could be.

\section{Sustainable value}

The idea of value leads to ponder further the relation between sustainability and value within business environments. Sustainability is stated to be one of the firm's key success factors in the long term business strategy (Kuosmanen \& Kuosmanen, 2009). Since firms use economic, environmental and social resources to produce goods and services to help the society to satisfy its needs, firms are at the same time both drivers and burdens to sustainable development (Hahn, Figge \& Barkemeyer, 2007). The sustainability performance of firms needs to be measured to encourage sustainability instead of burdening it.

The concept of sustainable value (SV) was developed by Figge and Hahn (2004) to measure firms' contributions to sustainability based on opportunity costs. The additional value created by a firm is measured ensuring that every environmental and social impact is in total constant because the idea of strong sustainability requires that each form of capital is kept constant. SV is inspired by the concept of strong sustainability, taking into account corporate eco- and social-efficiency as well as the absolute level of environmental and social resource consumption; in other words, the efficiency and effectiveness of all three dimensions of sustainability (Figge \& Hahn, 2004). The outcome of SV is a value that expresses how much more value is created because a firm is more efficient than a benchmark company and because the resources are allocated to the firm and not to benchmark companies (Figge \& Hahn, 2004). The target of SV is to measure the potential advantages from the reallocation of resources and to identify firms to or from which resources should be allocated (Kuosmanen \& Kuosmanen, 2009). SV steers businesses towards strong sustainability, hence enabling a stable economic position while adapting human activities - in this case business operations to meet the boundaries of natural resources.

By creating SV, firms are also acting as agents of sustainability transitions since the value creation process ultimately results in stronger sustainability performance. Consequently, the adoption of SV approach can support the firms meeting their sustainability targets at large. 
First, by adopting the SV approach, the company's business operations contribute to sustainability in all of its dimensions. Second, firms that engage in SV creation challenge the current system. Firms that have created SV have also benchmarked their operations. By gaining a leading position (regarding sustainability) in the markets, firms are able to apply pressure to their competitors. Eventually, this leads to increasing pressure on the whole business sector and at the same time on the prevailing regime. Also in this case, a firm's agency can be seen as two-dimensional: as agency towards the whole regime but on the other hand also as agency towards competing actors. If SV is closely associated with the concept of strong sustainability, the transition trajectory should proceed towards more radical innovations. However, various elements are likely to contribute to whether the competition caused by the SV approach results in transition pathways set by the parameters of the current regime or stir the transition more towards novel trajectories.

\section{Business models as tools for creating and capturing sustainable value}

The idea underlying sustainable value associated with business models is to unveil how SV is created, delivered and captured through business models. Den Ouden (2012)expressed the economic value for the expected users of the system, product or service to be the value for money, which reflects the usefulness of a product/service and value or the price of a product/service compared to the value or price of another product/service. The economic value that companies strive for is profit, and for an ecosystem it is financial stability and resilience. The economic value for society is summarized as wealth. The concepts of ecological value refer to an individual's ecological footprint, eco-effectiveness at a company level, sustainability at the ecosystem level and the livability of the environment at the society level. The livability of the environment relates to biodiversity as well as the physical beauty of nature. The social value for the user translates into belonging, which is an important parameter in determining people's happiness. At the company level, the social value is summarized as social responsibility, which represents the impact of a firm's behavior on society. Value at the ecosystem level from a social perspective translates into reciprocity, reflecting a system to which all parties contribute and from which they benefit. At the societal level, the ultimate value is the greatest happiness of the greatest number of people and meaningful life.

Sustainable business models propose sustainable value, but in practice, the value can be either captured or destroyed or missed (Bocken et al., 2013; 2015). Captured value represents the positive benefits delivered to users and other stakeholders. Destroyed value includes the negative outcomes of the business, such as greenhouse gas emissions, resource scarcity, biodiversity loss, unemployment, the neglect of health and safety, unfair competition and inequality. Missed value represents situations where stakeholders fail to capitalize on existing assets, capabilities and resources, or fail to benefit from the network, which might be due to poorly designed business models.

None of the companies on their own are able to achieve the system level goals (e.g. sustainability goals), but it is possible within a wider ecosystem where companies operate (Hellström et al., 2015). The business model of an individual company can reflect only part of the overall value creation, but it can be seen as a unit that serves a certain function in the ecosystem, thereby enabling system value creation. Firms can be interpreted as individual agents that trigger transitions that can gradually change the wider business environment and 
eventually the whole system. Hellström et al. (2015) summarize that the overall system-level value is created in the transactions and non-transactional links between the companies. Thus, to understand the sustainable value created and captured, value analysis and assessment at both the company level and the system level are needed. Sustainable value is created and captured on a system level, but the company level approach is equally important because the value capture of each individual company is ultimately the main incentive for engaging in collaboration.

On the way towards sustainable value creation and capture through business model innovation and strong sustainability, there is a wide range of recognized barriers in three primary areas: regulatory, market and financial, and behavioral and social barriers (Laukkanen \& Patala, 2014). It is obvious that companies and regulatory bodies need to take individual and combined action to overcome all these. Companies' task is to create new radical innovations towards sustainability, and well-functioning, consistent and long-term regulatory frameworks should support this development by creating a favorable innovation environment (e.g. Hekkert et al., 2007). To accelerate the transition towards strong sustainability, companies must not remain passive with respect to the system level either, but rather collaborate actively with relevant stakeholders to form common norms that support the creation of sustainable business model innovations.

\section{Preliminary frameworks for integrated sustainability through different disciplines}

Synergy between corporate sustainability, business model and system transition literature The main theoretical elements of the literature review were sustainability, business model and system transition. In this chapter, the synergy between these elements emerges as sustainable business models that create sustainable value. Since none of the companies on their own are able to achieve the system level goals of sustainable development through their business models, system transition had to be integrated into business studies.

Sustainability literature emphasizes the dichotomy of strong and weak sustainability (Williams \& Millington 2004). The distinction between strong and weak sustainability describes the general target levels of sustainability. The underlying assumption is that firms should pursue strong sustainability to shift the paradigm towards a sustainable society even if weak sustainability were an improvement compared to the previous circumstances. The literature suggests that companies are able to pursue different levels of sustainability. For example, both business model literature and literature on system transition recognizes firms' sustainability transition capabilities (i.e. Cavalcante et al., 2011; Boons et al., 2013; Geels, 2014). In addition, both disciplines acknowledge that businesses are also able to orientate themselves more towards radical innovations or niche-driving transitions if enough pressure is expected from other system actors or from stakeholders (i.e. Cavalcante et al., 2011; Boons et al., 2013; Geels, 2014). In the literature of business model change, the pathway towards strong sustainability is perceived as a trajectory from incremental innovation through business model innovation and business model redesign to radical innovation (i.e. Boons et al., 2013; Gauthier \& Gilomen, 2016). System transition portrays a similar path from a sustainability transition set by the parameters of the current regime through transition where the current regime adopts niche innovations eventually to sustainability transition where niche innovation pressure alters the current regime (i.e. Geels \& Schot, 2007; Geels, 2014). 
Corporate sustainability literature also recognizes the pathway from weak sustainability to strong sustainability. In the corporate responsibility literature, the trajectory is seen as an ongoing process from business as usual through refined shareholder management and triple bottom line management to truly sustainable business (i.e. Dyllick \& Muff, 2015). This implies that in the literature of different disciplines, the terminology varies but the actual phenomena often overlap. To sum up the interdisciplinary literature review, an integrative conceptual framework is proposed in Figure 2 as the outcome of the analysis.

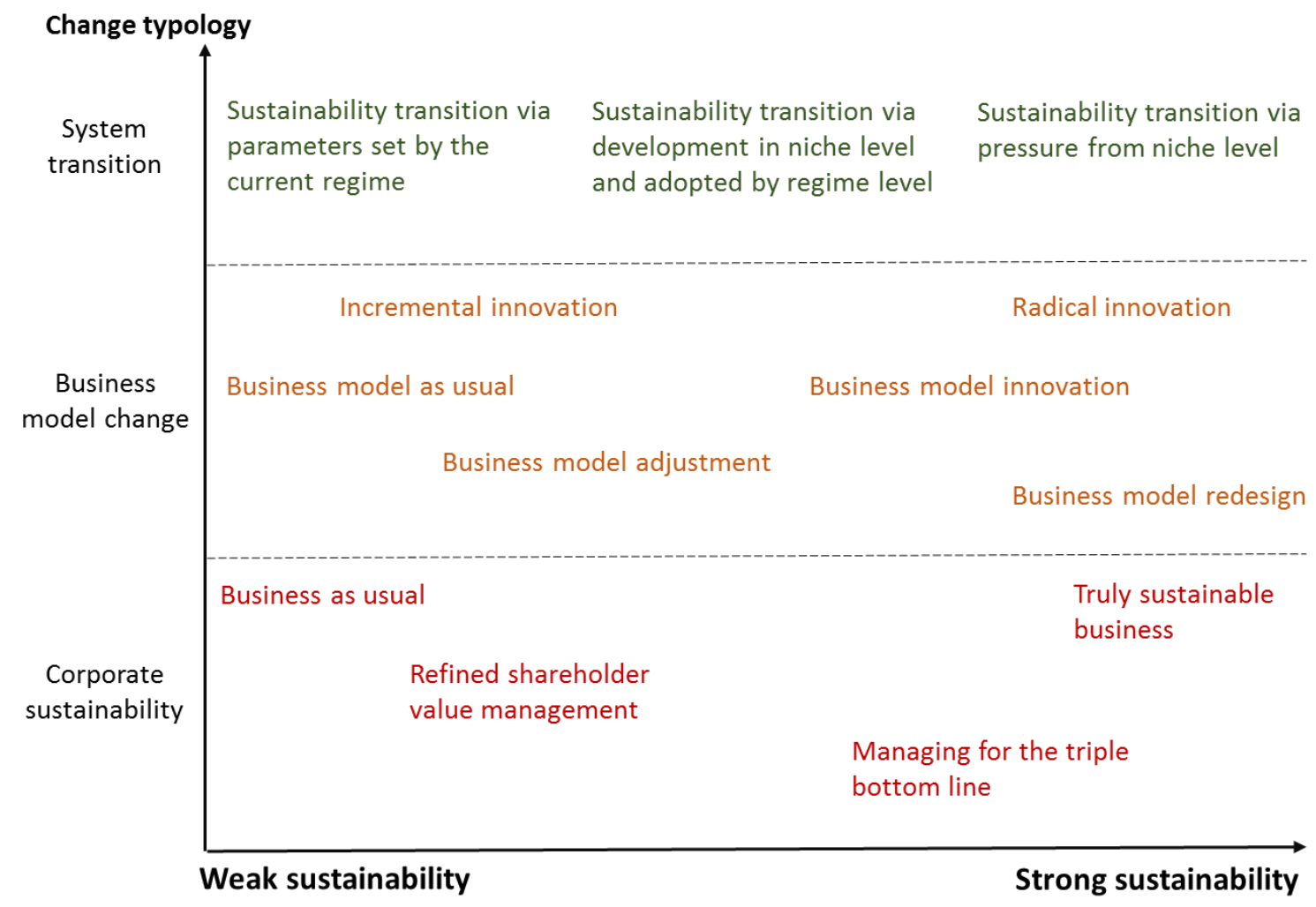

Figure 2. Proposed integrative framework (adapted from Geels, 2014; Gauthier \& Gilomen, 2016; Dyllick \& Muff, 2015)

Despite the scattered terminology, the capability of firms to create sustainability through agency and sustainable value through business models is acknowledged. The proposed integrative framework could be utilized in the future in analyzing new sustainable business models, system value, and value creation and capture, and eventually in evaluating how strong the sustainability performance of the company is. The proposed framework is an outline that employs a variety of terms for similar phenomena. Understanding similar phenomena in different disciplines may help to reduce the current gap between literatures of system transition and business models.

Illustrations of phenomena are always simplifications of reality, and Figure 2 demonstrates the pathway towards strong sustainability rather roughly. On the end of "weak sustainability" is "business as usual", "incremental innovation", and "sustainability transition via parameters set by the current regime" - not because these phenomena could not contribute to 
sustainability but because they are typically strongly restricted by the existing environment and hence unable to meet their full sustainability potential. For example, typical end-of-pipe methods that remove already formed emissions do contribute to sustainability but not to the extent as new material saving technology. At the other end of the line, "strong sustainability" encompasses "truly sustainable business", "radical innovation", and "sustainability transition via pressure from the niche level". Figure 2 shows that these phenomena pursue strong sustainability through "refined shareholder value management", "triple bottom line management", "business model adjustment", "business model innovation", and "sustainability transition via development in niche and adopted by regime". The reason why radical innovation and sustainability transition via niche pressure are situated at the end of the strong sustainability is because the radical innovations and niche pressure help the business to overcome the lock-in mechanisms set by the current regime and become truly sustainable.

In reality, the phenomena might overlap also in a vertical sense. In addition, there are multiple transition trajectories, and for that reason, Figure 2 does not imply that only radical innovations are relevant to achieve holistic sustainability. Sustainability transitions are effected, for example, by timing and spatial conditions (Geels \& Schot, 2007; Markard \& Truffer, 2008). Radical innovations are needed in addition to incremental innovation to achieve major sustainability changes, transform industries and consequently move towards strong sustainability and truly sustainable businesses.

\section{Integration of business model change towards sustainability and system transition}

The gap between the system transition research and business model literature remains clear. For example, Markard and Truffer (2008) presented the synergies and differences of transition literature and innovation studies, but the holistic integration is still incompletely researched. Business model literature pays little attention to system level effects on the process of business model change; instead, the focus stays on the company's internal operations (e.g. Abdelkafi \& Täuscher, 2016; Gorissen et al., 2016). Transition literature emphasizes system level changes and underplays the role of individual companies. Recently, Geels (2014) emphasized the need for bidirectional interaction between firms and larger systems in the new conceptual framework, TEF. However, these attempts still overlook firms' internal operations. Firms are mainly interpreted as external agents of sustainability transition.

Moreover, the business model literature often leans on reliance on market forces (i.e Dyllick \& Muff, 2015; Gauthier \& Gilomen, 2016). On one hand, relying solely on markets involves the risk that sustainable development remains slow and weak since markets are driven by other incentives. On the other hand, transition theory often emphasizes governmental steering in creating sustainability (i.e. Geels, 2002; Geels, 2010; Smith et al., 2010; Berkhout et al., 2005). Consequently, the operation of companies is restricted by laws and regulations. This implies that business model literature would need stronger understanding of how policy pressure or governmental steering influences business model change and hence also value capture. In turn, transition literature would benefit from more detailed knowledge of how firms' internal operations affect sustainability transitions and how the agency of firms is represented. Figure 3 visualizes the integration of the two disciplines. The framework is a 
tentative proposal for the early integration of business model change literature and system transition literature, and therefore, it also has several simplifications.

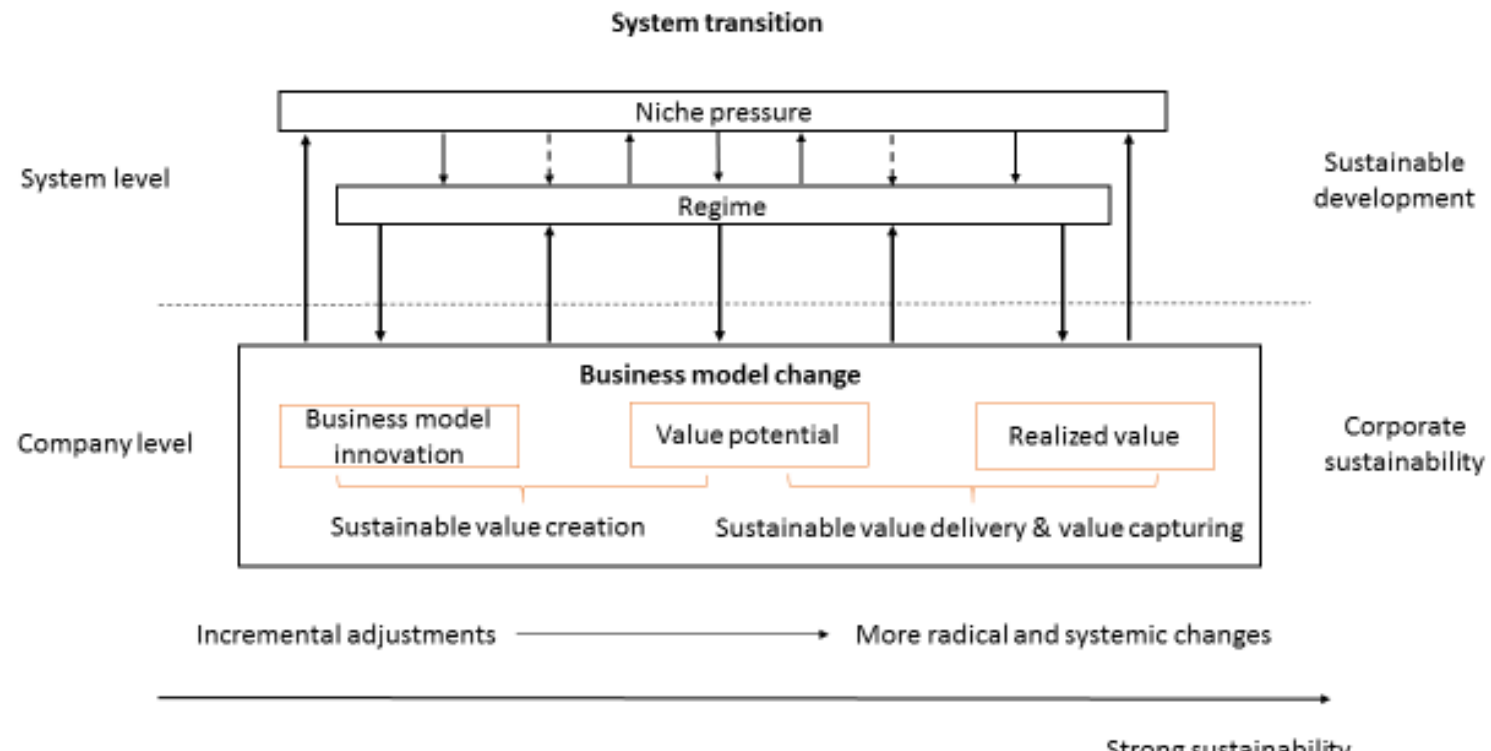

Figure 3. Tentative integration of business model change and system transition

At the company level, the framework introduces business model change towards strong sustainability. The idea underlying sustainable business model is to create economic, ecological, social and psychological benefits for the wide range of stakeholders in the society where the firm operates, to enhance corporate responsibility and further sustainable development. The framework illustrates that the potential and impacts of the sustainable business models are measured through sustainable value created, delivered and captured. First, the idea of business model change towards sustainability is to strengthen the value propositions, i.e. value potential through the business model elements (Osterwalder \& Pigneur, 2010), such as key resources, key activities and partnerships that are needed to create value. Second, the framework highlights the fact that the potential value is not always equal to the actual realized value. Potential value can be either captured, destroyed or missed (Bocken et al., 2013; 2015). The overall objective is to increase the realized sustainable value through different value delivery and capture mechanisms. The framework shows that firms can have a dualistic role in their aspirations to meet their sustainability targets. First, by adopting the sustainable value approach, firms contribute to sustainability within all of the firm's dimensions. Second, firms that engage in sustainable value creation challenge the current system. Actions of businesses pursuing sustainability are interpreted as agency that appears both within individual firms but also within the wider business environment. Firms are able to act as internal sustainability agents through business model change in addition to simply being external agents of sustainability transition. On the other hand, literature (i.e. Hellström et al., 2015; Geels, 2014) stated that individual firms are not able to achieve the system level goals, i.e. sustainable development, since for that bidirectional actions within firms and a wider ecosystem where firms operate are also highlighted. Regime pressure can affect both created potential value and realized value positively or negatively. 
At the system level, the framework introduces a sustainable regime towards sustainability. To achieve strong sustainability, a sustainability oriented regime is needed as a gatekeeper for (1) unsustainable niche innovations and for (2) steering through policies or through a regime's legitimacy, business environments towards business model change and hence to capturing sustainable value. Niche pressure is emphasized because niche agency often enables sustainability transitions by driving innovations, implementing regime changes and eventually connecting niche and regime levels (Grin, Rotmans \& Schot, 2011). Niche agency is crucial for sustainability transitions since it bears the potential for system level changes and radical innovations (Geels, 2011). This implies that niche pressure is needed for effective sustainability transitions.

Since stable regimes are the outcome of various lock-in mechanisms, they typically reinforce themselves against innovations (Klitkou et al., 2015). This means that regime actors are constrained by parameters from the existing regime. Hence, sustainability transitions enacted by regime actors were found to be path-dependent and trajectories are set by the current regime, thereby evolving through incremental innovation (Geels \& Schot 2007). The regime can be a significant barrier for radical innovation to overcome, and typically radical innovations occur only if they are protected in niches (Markard \& Truffer, 2008). In reality, transitions happen through multiple trajectories. The interactions of niche and regime levels should be studied more since regime actors may have ambivalent motivations (Bakker, 2014). As lock-in mechanisms typically reinforce a certain pathway of transition, the opportunity of upscaling a given niche depends on the characteristics of the regime in question (Klitkou et al., 2015). For example, Geels and Schot (2007) have presented four different pathways for sustainability transitions: transformation, reconfiguration, technological substitution, and dealignment and realignment. They have also noted that certain transition pathways can shift from one to another. This suggests that even if niche pressure is often crucial for sustainability transitions multilevel interactions are evident and regime conditions, such as policy drivers, also play a role in the transition process. Further, both company level and system level components that create or hinder sustainability transitions need to be concretized in more detail.

\section{CONCLUSION}

This work contributes theoretically to existing sustainable business model literature in three ways. First, the paper presents how sustainable business models can be used to create sustainable value. Sustainable value is captured through business model change from business as usual to truly sustainable business. Challenges in sustainable development, and therefore in corporate sustainability, in business model change and value capture are related to the poor integration of the system level and company level and also to the slow progress towards strong sustainability. However, a firm's capability to act as an agent of sustainability is acknowledged through different disciplines. Sustainable value steers firms towards strong sustainability, hence creating possibilities for a stable economic position while adapting human activities - in this case business operations - to meet the boundaries of natural resources. Hence, value creation can be interpreted as a bridge to sustainable business and later as a component of larger system level transition. 
Secondly, the paper presents pathways towards sustainability in relation to companies in different disciplines. Different disciplines use scattered and often overlapping terminology to describe the change from weak sustainability to strong sustainability. A stronger understanding of overlapping typology, while the phenomena remain much the same, can ultimately advance the integration of different disciplines.

Thirdly, the findings imply that there is still a lack of integration between system level (system transition) and company level (business model change). To adopt sustainable business models and hence sustainable value, firms need to consider system level influences on the change process. Since the current regime strongly puts pressure on firms' operations - for example, via legislation - a sustainable regime would assist companies in adopting sustainable business models. To achieve strong sustainability, more synergies between the system level and business environments is needed. This interplay between policy oriented system transition and business model change that focuses on business environments could also be associated with private-public partnerships that aim for cooperation between the public and private sectors.

The focus was theoretical. Since it is likely that the somewhat scattered phenomenon of firms acting as intermediates of sustainability is close to operationalization, the framework should be tested empirically to see the actual adjustment of the framework in business environments. 


\section{REFERENCES}

Abdelkafi, N., \& Täuscher, K. (2016), Business models for sustainability from a system dynamics perspective, Organization and Environment, 29(1), 74-96.

Amit, R., \& Zott, C. (2012), Creating value through business model innovation, MIT Sloan Management Review, 53(3), 41-49.

Anderson, J.C., Narus, J.A. \& van Rossum, W. (2006), Customer Value Propositions in Business Markets, Harvard Business Review, 84(3), 91-99.

Bakker, S., van Lente, H. \& Engels, R. (2012), Competition in a technological niche - the cars of the future, Technology Analysis and Strategic Management, 24 (5), 421-434.

Bakker, S. (2014). Actor rationales in sustainability transitions - Interests and expectations regarding electric vehicle recharging. Environmental Innovation and Societal Transitions, 13, 60-74.

Ballantyne, D., Frow, P., Varey R.J. \& Payne, A. (2011), Value propositions as communication practice: Taking a wider view, Industrial Marketing Management, 40 (2011), 202-210.

Bardhi, F., \& Eckhardt, G.M. (2012), Access-based consumption: The case of car sharing, Journal of Consumer Research, 39(4), 881-898.

Baden-Fuller, C. \& Morgan, M.S. (2010), Business models as models, Long range planning, 43(2-3), 156-171.

Baumgartner, R. J. \& Ebner, D. (2010), Corporate sustainability strategies: Sustainability profiles and maturity levels, Sustainable Development, 18(2), 76-89.

Bergek, A., Hekkert, M., Jacobsson, S., Markard, J., Sandén, B., \& Truffer, B. (2015), Technological innovation systems in contexts: Conceptualizing contextual structures and interaction dynamics, Environmental Innovation and Societal Transitions, 16, 51-64.

Berkhout, F., Smith, A., \& Sterling, A. (2005), Socio-technological regimes and transition contexts, In Boelie Elzen, Frank Geels and Ken Green (eds), System Innovation and the Transition to Sustainability: Theory, Evidence and Policy, Camberley: Edward Elgar Publishing

Bocken, N.M.P., Rana, P., \& Short, S.W. (2015), Value mapping for sustainable business thinking, Journal of Industrial and Production Engineering, 32(1), 67-81.

Bocken, N.M.P, Short, S.W., Rana, P. \& Evans, S. (2013), A value mapping tool for sustainable business modelling, Corporate Governance (Bingley), 13(5), 482-497.

Bocken, N. M. P., Short, S. W., Rana, P., \& Evans, S. (2014), A literature and practice review to develop sustainable business model archetypes, Journal of Cleaner Production, 65, 42-56.

Boons, F. \& Lüdeke-Freund, F. (2013), Business models for sustainable innovation: State-ofthe-art and steps towards a research agenda, Journal of Cleaner Production, 45, 9-19.

Boons, F., Montalvo, C., Quist, J. \& Wagner, M. (2013), Sustainable innovation, business models and economic performance: An overview, Journal of Cleaner Production, 45, 1-8.

Bork, S., Schoormansb, J., Silvester, S., \& Joored, P. (2015), How actors can influence the legitimation of new consumer product categories: A theoretical framework, Environmental Innovations and Societal Transitions, 16, 36-50. 
Carayannis, E.G., Sindakis, S. \& Walter, C. (2014), Business Model Innovation as Lever of Organizational Sustainability, Journal of Technology Transfer, 40(1), 85-104.

Casadesus-Masanell, R., \& Ricart, J.E. (2010), From strategy to business models and onto tactics, Long range planning, 43(2-3), 195-215.

Cavalcante, S., Kesting, P., \& Ulhøi, J. (2011), Business model dynamics and innovation: (re)establishing the missing linkages, Management Decision, 49(8), 1327-1342.

Chaurey, A., Krithika, P. R., Palit, D., Rakesh, S., \& Sovacool, B. K. (2012), New partnerships and business models for facilitating energy access, Energy Policy, 47(SUPPL.1), 48-55.

Chesbrough, H. \& Rosenbloom, R.S. (2002), The role of the business model in capturing value from innovation: Evidence from Xerox Corporation's technology spin-off companies, Industrial and Corporate Change, 11(3), 529-555.

Dyllick, T. \& Muff, K. (2015), Clarifying the Meaning of Sustainable Business: Introducing a Typology from Business-as-Usual to True Business Sustainability, Organization and Environment, 29(2), 156-174.

Ebner, D. \& Baumgartner, R. (2006), The relationship between Sustainable Development and Corporate Social Responsibility, Corporate Responsibility Research Conference, 4th-5th September, Dublin, Ireland.

Figge, F. \& Hahn, T. (2004), Sustainable value added - measuring corporate contributions to sustainability beyond eco-efficiency, Ecological Economics, 48(2), 173-187.

Fudge, S., Peters, M. \& Woodman, B. (2016), Local authorities as niche actors: the case of energy governance in the UK, Environmental Innovation and Societal Transitions, 18, 1-17.

Gauthier, C \& Gilomen, B. (2016), Business Models for Sustainability: Energy Efficiency in Urban Districts, Organization \& Environment, 29(1), 124-144.

Geels, F. (2002), Technological transitions as evolutionary reconfiguration processes: a multilevel perspective and a case-study, Research Policy, 31, 1257-1274.

Geels, F. (2010), Ontologies, socio-technical transitions (to sustainability), and the multi-level perspective, Research Policy, 39, 495-510.

Geels, F. (2011), The multi-level perspective on sustainability transitions: Responses to seven criticisms, Environmental Innovation and Societal Transitions, 1(1), 24-40.

Geels, F. (2014), Reconceptualising the co-evolution of firms-in-industries and their environments: Developing an inter-disciplinary Triple Embeddedness Framework, Research Policy, 43, 261- 277.

Geels, F. \& Schot, J. (2007), Typology of sociotechnical transition pathways, Research Policy, 36(3), 399-417.

Geels, F. \& Verhees, B. (2011), Cultural legitimacy and framing struggles in innovation journeys: a cultural-performative perspective and a case study of Dutch nuclear energy (19451986), Technological Forecasting and Social Change, 78(6), 910-930.

Genus, A., \& Coles, A.-M. (2008). Rethinking the multi-level perspective of technological transitions, Research policy, 37, 1436-1445. 
Gorissen, L., Vrancken, K. \& Manshoven, S. (2016), Transition thinking and business model innovation-towards a transformative business model and new role for the reuse centers of Limburg, Belgium, Sustainability (Switzerland), 8(2), 1-23.

Grin, J., Rotmans, J., \& Schot, J. (2011), On patterns and agency in transition dynamics: Some key insights from the KSI programme, Environmental Innovation and Societal Transitions, 1, 76-81.

Hahn, T., Figge, F. \& Barkemeyer, R. (2007), Sustainable value creation among companies in the manufacturing sector, International Journal of Environmental Technology and Management, 7(5), 496-512.

Haxeltine, A. \& Seyfang, G. (2009), Transitions for the People: Theory and practice of 'Transition' and 'Resilience' in UK's Transition Movement. Tyndall Centre for Climate Change Research, Norwich. Working Paper 134, Available at: http://www.tyndall.ac.uk/sites/default/files/twp134.pdf (accessed 01.03.17).

Heijden, A., van der Cramer, J. \& Driessen, P. (2012), Change agent sensemaking for sustainability in a multinational subsidiary, Journal of Organizational Change Management, 25 (4), 535-559.

Hekkert, M. P., Suurs, R. A. A., Negro, S. O., Kuhlmann, S., \& Smits, R. E. H. M. (2007), Functions of innovation systems: A new approach for analysing technological change, Technological Forecasting and Social Change, 74(4), 413-432.

Hellström, M., Tsvetkova, A., Gustafsson, M., \& Wikström, K. (2015), Collaboration mechanisms for business models in distributed energy ecosystems, Journal of Cleaner Production, 102, 226-236.

Johnson, M.W. \& Suskewicz, J. (2009), How to jump-start the clean-tech economy, Harvard business review, 87(11).

King, B. (2008), A Social Movement Perspective of Stakeholder Collective Action and Influence, Business \& Society, 47(1), 21-49.

Klitkou, A., Bolwig, S., Hansem, T. \& Wessberg, N. (2015), The role of lock-in mechanisms in transition processes: The case of energy for road transport, Environmental Innovation and Societal Transitions, 16, 22-37.

Kuosmanen, T. \& Kuosmanen, N. (2009), How not to measure sustainable value (and how one might), Ecological Economics, 69, 235-243.

Lacy, P., Haines, A. \& Hayward, R. (2012), Developing strategies and leaders to succeed in a new era of sustainability: Findings and insights from the United Nations Global CompactAccenture CEO Study, Journal of Management Development, 31(4), 346-357.

Laukkanen, M. \& Patala, S. (2014), Analysing the barriers to sustainable business model innovations: innovation systems approach, International Journal of Innovation Management, 18(6).

Lehner, M. (2015), Translating sustainability: the role of the retail store, International Journal of Retail \& Distribution Management, 43(4), 386-402.

Lewandowski, M. (2016), Designing the business models for circular economy-towards the conceptual framework, Sustainability (Switzerland), 8(1), 1-28. 
Linnenluecke, M.K. \& Griffiths, A. (2013), Firms and sustainability: Mapping the intellectual origins and structure of the corporate sustainability field, Global Environmental Change, 23(1), 382-391.

Markard, J., \& Truffer, B. (2008), Technological innovation systems and the multi-level perspective: Towards an integrated framework, Research Policy, 37, 596-615.

Marshall, C. \& Rossman, G., B. 1999. Designing qualitative research. Sage Publications. Thousands Oaks-London-New Delhi. 224 p.

Milne, M. J., Kearins, K. \& Walton, S. (2006), Creating adventures in Wonderland: the journey metaphor and environmental sustainability, Organization, 13, 801-39.

Mikkilä, M. 2006. The many faces of responsibility: Acceptability of the global pulp and paper industry in various societies. Dissertationes Forestales 25. http://www.metla.fi/dissertationes/df25.pdf.

Mikkilä, M., Panapanaan, V. \& Linnanen, L. (2015), Corporate responsibility in Finland - From local movements to global responsibility. In Idowu, S. O., Schmidpeter, R., Fifka, M. S. (Eds.), Corporate Social Responsibility in Europe (pp. 209-228). Springer. Available at: http://link.springer.com/chapter/10.1007\%2F978-3-319-13566-3_12

Mikkilä, M., Panapaan, V. \& Linnanen, L. (2016), The Pursuit of Responsible Business: Corporate Responsibility of Finnish Companies in Their Global Operations. Chapter 8 in Idowu, S. (ed.): Key Initiatives in Corporate Social Responsibility, CSR, Sustainability, Ethics \& Governance. Springer. DOI 10.1007/978-3-319-21641-6_8.

Mikkilä, M. \& Toppinen, A. (2008), A qualitative analysis of corporate responsibility reporting in the world's largest pulp and paper companies. Forest Policy and Economics 8: 500-506. DOI 10.1016/j.forpol.2008.05.002.

Miles, M. B. \& Huberman, A. M. 1994. Qualitative data analysis. An expanded sourcebook. Sage Publications, Thousands Oaks-London-New Delhi. 338 p.

Nidumolu, R., Prahalad, C.K. \& Rangaswami, M.R. (2009), Why sustainability is now the key driver of innovation, Harvard business review, 87(9).

Osterwalder, A., \& Pigneur, Y. (2010), Business model generation. A handbook for visionaries, game changers, and challengers. New Jersey: John Wiley \& Sons.

Den Ouden, E. (2012), Innovation design. Creating value for people, organizations and society. Springer.

Pedersen, E.R.G., Gwozdz, W. \& Hvass, K.K. (2016), Exploring the Relationship Between Business Model Innovation, Corporate Sustainability, and Organisational Values within the Fashion Industry, Journal of Business Ethics, article in press, 1-18. doi:10.1007/s10551-0163044-7

Planing, P. (2015), Business Model Innovation in a Circular Economy Reasons for NonAcceptance of Circular Business Models. Open Journal of Business Model Innovation, available online http://www.scipublish.com/journals/BMI/papers/1250

Rizzi, F., Bartolozzi, I., Borghini, A., \& Frey, M. (2013), Environmental management of end-oflife products: Nine factors of sustainability in collaborative networks, Business Strategy and the Environment, 22(8), 561-572. 
Rockström, J., Steffen, W., Noone, K., Persson, Å., Chapin, F., Lambin, E., Lenton, T., Scheffer, M., Folke, C., Schellnhuber, H., Nykvist, B., de Wit, C., Hughes, T., van der Leeuw, S., Rodhe, H., Sörlin, S., Snyder, P., Costanza, R., Svedin, U., Falkenmark, M., Karlberg, L., Corell, R., Fabry, V., Hansen, J., Walker, B., Liverman, D., Richardson, K., Crutzen, P., \& Foley, J. (2009), A safe operating space for humanity, Nature, 461 (22), 472-475.

Schaltegger, S., Lüdeke-Freund, F. \& Hansen, E.G. (2012), Business cases for sustainability: The role of business model innovation for corporate sustainability, International Journal of Innovation and Sustainable Development, 6(2), 95-119.

Schaltegger, S., Hansen, E. G., \& Lüdeke-Freund, F. (2016), Business models for sustainability: Origins, present research, and future avenues, Organization and Environment, 29(1), 3-10.

Short, S. W., Bocken, N. M. P., Barlow, C. Y., \& Chertow, M. R. (2014), From refining sugar to growing tomatoes: Industrial ecology and business model evolution, Journal of Industrial Ecology, 18(5), 603-618.

Smith, A., Stirling, A., \& Berkhout, F. (2005), The governance of sustainable socio-technical transitions, Research Policy, 34, 1491-1510.

Smith, A., Voß, J.-P., \& Grin, J. (2010), Innovation studies and sustainability transitions: The allure of the multi-level perspective and its challenges, Research Policy, 9(4), 435-448.

Steffen, W., Richardson, K., Rockström, J., Cornell, S.E. Fetzer, I. et al. (2015), Planetary boundaries: Guiding human development on a changing planet, Science.

Stubbs, W. \& Cocklin, C. (2008), Conceptualizing a "sustainability business model", Organization and Environment, 21(2), 103-127.

Teece, D.J. (2010), Business models, business strategy and innovation, Long range planning, 43(2-3), 172-194.

Tukker, A. (2015), Product services for a resource-efficient and circular economy - A review, Journal of Cleaner Production, 97, 76-91.

Upward, A., \& Jones, P. (2016), An ontology for strongly sustainable business models: Defining an enterprise framework compatible with natural and social science, Organization and Environment, 29(1), 97-123.

Vargo, S. L., Lusch, R. F. and Morgan, F. W. (2006) Historical perspectives on service-dominant logic. In The Service-Dominant Logic of Marketing: Dialog, Debate and Directions, (eds) R. F. Lusch and S. L. Vargo, pp. 29-42. M.E. Sharpe Inc., Armonk, New York.

Walker, G., Devine-Wright, P., Hunter, S., High, H. \& Evans, B. (2010), Trust and community: exploring the meanings, contexts and dynamics of community renewable energy. Energy Policy 38, 2655-2663.

WCED. (1987), WCED Our Common Future. World Commission on Environment and Development. Oxford University Press, Oxford (1987)

Whiteman, G., Walker, B., \& Perego, P. (2013), Planetary boundaries: Ecological foundations for corporate sustainability, Journal of Management Studies, 50(2), 307-336.

Wiek, A., Ness, B., Schweizer-Ries, P., Brand, F., \& Farioli, F. (2012), From complex systems analysis to transformational change: a comparative appraisal of sustainability science projects, Sustainability Science, 7(1), 5-24. 
Williams, C. \& Millington, A. (2004), The diverse and contested meanings of sustainable development, The Geographical Journal, 170(2), 99-104.

Woodall, T. (2003). Conceptualising 'value for the customer': An attributional, structural and dispositional analysis. Academy of Marketing Science Review, 2003, 12.

Zott, C. \& Amit, R. (2007), Business model design and the performance of entrepreneurial firms, Organization Science, 18(2), 181-199.

Zott, C. \& Amit, R. (2010), Business model design: An activity system perspective, Long range planning, 43(2-3), 216-226.

Zott, C., Amit, R. \& Massa, L. (2011), The business model: Recent developments and future research, Journal of Management, 37(4), 1019-1042. 